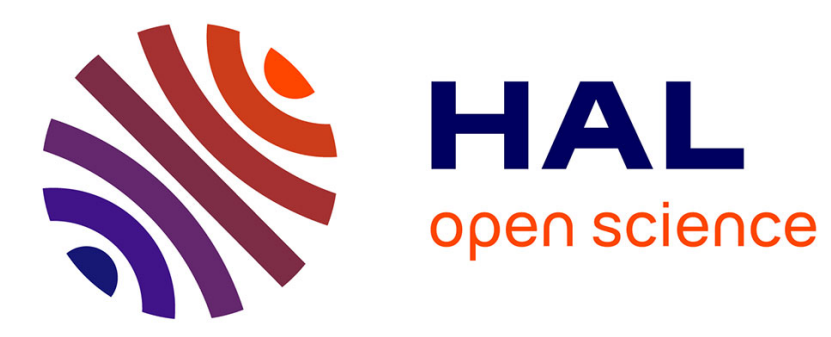

\title{
What history tells us XXXVIII. Resurrection of a transient forgotten model of gene action.
}

Michel Morange

\section{To cite this version:}

Michel Morange. What history tells us XXXVIII. Resurrection of a transient forgotten model of gene action. . Journal of Biosciences, 2015. hal-01346375

\section{HAL Id: hal-01346375 \\ https://hal.science/hal-01346375}

Submitted on 27 Jul 2016

HAL is a multi-disciplinary open access archive for the deposit and dissemination of scientific research documents, whether they are published or not. The documents may come from teaching and research institutions in France or abroad, or from public or private research centers.
L'archive ouverte pluridisciplinaire HAL, est destinée au dépôt et à la diffusion de documents scientifiques de niveau recherche, publiés ou non, émanant des établissements d'enseignement et de recherche français ou étrangers, des laboratoires publics ou privés.

\section{(1) (1) $\$$}

Distributed under a Creative Commons Attribution - NonCommercial - NoDerivatives| 4.0 


\section{What history tells us}

\section{XXXVIII.}

Resurrection of a transient forgotten model of gene action MICHEL MORANGE

Centre Cavaillès, République des Savoirs: lettres, sciences, philosophie USR 3608, Ecole normale supérieure, 29 rue d'Ulm, 75230 Paris Cedex 05, France

(Fax, 33-144-323941; Email, morange@biologie.ens.fr)

Keywords: embryonic induction; hormone; one gene - one enzyme relation; organizer

\section{An incoherent historical description of the path to the one gene - one enzyme relation}

The one gene - one enzyme relation of George Beadle and Edward Tatum is one of the pillars of molecular biology. The numerous steps that led to its emergence have been well described by historians. Alfred Sturtevant observed the partial correction of the vermilion mutation in Drosophila gynandromorphs. He interpreted it as the result of the diffusion of a substance present in the wild-type tissues surrounding the eye bud (Sturtevant 1920 and 1932). Under his influence, Beadle and Boris Ephrussi initiated their experiments on the genetic determinism of eye colour in Drosophila, using the embryological technique of eye bud transplantation (Beadle and Ephrussi 1935 and 1937). They spent long years characterizing the chemical nature of the diffusible substances involved (Thimann and Beadle 1937; Tatum and Beadle 1940). This work was a failure, since the chemical nature of these substances was first described by Adolf Butenandt in Germany (Butenandt et al. 1940). Finally, Beadle and Tatum successfully reoriented their work by 
reversing the experimental approach, and looking at the genetic control of well-known metabolic pathways in a new model organism, Neurospora (Beadle and Tatum 1941). Hans-Jörg Rheinberger has shown how the German biologists Alfred Kühn and Ernst Caspari, before Beadle and Tatum, developed a similar and independent study on the flour moth Ephestia. They obtained identical results, and proposed similar hypotheses (Rheinberger 2000). The work was partially interrupted by war and has not been fully recognized by the scientific community and by historians.

Even complemented by the contribution of Kühn and Caspari, this historical presentation remains puzzling. What Beadle and Tatum, as well as Kühn and Caspari, initially aimed at were the mechanisms of gene action in development, whereas the relation finally established between genes and enzymes was general and, moreover, not new: Archibald Garrod, L. T. Troland, John Haldane and Muriel Wheldale among others had already proposed a similar relation (Olby 1974). Additional difficulties emerge when the initial work of Beadle and Ephrussi is closely scrutinized. Among the more than twenty mutations that affected eye colour, they focused their attention on two non-autonomous mutations, i.e. mutations that could be corrected by surrounding wild-type tissues in mosaic animals. Apart from a reference to Sturtevant's earlier observations, the reasons for focusing, from the outset, on non-autonomous characters are not obvious. In addition, Beadle and Ephrussi used the word "hormone" to designate the nature of the substances involved, and this habit persisted up to 1940 for Beadle (Tatum and Beadle 1940) and 1944 for Ephrussi (Ephrussi and Herold 1944) - the same word was used by Kühn. To characterize the substances involved, Beadle recruited a specialist of auxin, a plant hormone, to help him in the work! 
A last surprising observation is that Beadle introduced the one gene - one enzyme relation belatedly (Beadle 1945), and marginally. Obviously, the establishment of this relation was not what guided the choice of Neurospora nor does it explain the importance attributed to the first results obtained on this system.

Historians (and biographers) have already noticed these "abnormalities". Some present them as oddities without significance, the use of "loosely defined" terms: the word "hormone" is often placed between inverted commas when this early work is described (Horowitz 1990, 2; Kay 1993; Berg and Singer 2003). Gayon has particularly emphasized the recurrent and late use of the word "hormone" to designate the substances involved in the coloration of the eyes, and shown that the model that Ephrussi had in mind was clearly different from the one gene - one enzyme relation (Burian et al. 1991; Gayon 1994). Rheinberger has highlighted Kühn's hormonal interpretation of his results (Rheinberger 2000). Nevertheless, I think that it is possible to go further: there was a model of gene action that was shared by most of the participants. It was a tacit, rarely fully explicit model. It also included evidence obtained by Hans Spemann on the existence of embryonic inducers and of an organization centre, as well as the recent efforts initiated by Joseph Needham to characterize the chemical nature of the latter.

\section{The model and its supports}

The model was very simple. It proposed that one of the functions of genes was to control the production or action of hormones. These hormones behaved as embryonic inducers, which explained how genes were able to control development. The model found strong support in the importance attributed to hormones in physiological processes, and in the rapid 
progress made in their characterization. It was obvious in the 1930s that hormones controlled differentiation and development: such was the case of the growth and thyroid hormones (the latter being involved in the metamorphosis of amphibians), but also of steroid and in particular sexual hormones. Interestingly, vitamin D was also a steroid derived from cholesterol, and this observation established a link between hormones and other important objects of research in biochemistry, vitamins: vitamin D was also important for bone formation. Observations of hormone action on development, and of their control by genes, were obtained in plants (van Overbeek 1935)

The link between embryonic inducers and hormones was not introduced by Spemann, but proposed in 1931 by Joseph Needham in his monumental book on chemical embryogenesis (Needham 1931). He suggested that the substance responsible for the effects of the organizer was a steroid, and the first results of the purification of the active principle present in the organizer seemed to support this view (Armon 2012).

To consider that the products of genes were hormones fully agreed with the vision of genes as "controllers". Slightly later Conrad Waddington, faced with the paradox that artificial substances were able to mimic the action of the organizer, proposed the idea that the substance present in the organizing centre acted as an evocator, switching on a response that was already predetermined in the recipient tissue (Waddington 1936). This idea was not incompatible with this conception of gene action, considered as essential but limited. We need to take off our present-day information glasses in order to understand how the function of genes was viewed in the 1930s!

\section{Evidence for the existence of this model}


One difficulty is that the model was never fully and clearly made explicit. There are probably two reasons for this cautious attitude of biologists. The first was that there were other models of gene action, which had never been cast aside: in particular, the case of the relation between genes and enzymes. Most of the mutations controlling eye development were autonomous, demonstrating the existence of mechanisms of gene action other than the hormonal one (see later). In addition, the way genes might control the production or action of hormones was totally unknown. The second reason was that the model was at the crossroads of different disciplines and attempts to establish relations between three highly different areas of research: biochemistry (including the study of hormones and vitamins), embryology, and genetics. To present the model explicitly generated the risk of being harshly criticized by specialists of other disciplines.

A second difficulty is the huge effort necessary to abandon our current vision and to read the publications of Beadle, Ephrussi and Kühn without interpreting their results in terms of presentday understanding. When they describe the successive roles of genes in the production of substances, we must not immediately substitute a model in which genes give rise to enzymes that control the successive steps of a metabolic pathway. This interpretation progressively emerged from the experimental observations, both in the case of Beadle and Ephrussi and of Kühn: it was not the interpretation that guided the initial work, in contradiction with the authors' own retrospective reading of their work (Beadle 1974). Despite a lack of a direct evidence for the existence and importance of the hormonal model, I believe that the strongest argument in its favour is that it provides an explanation for the puzzling observations that I outlined before. The use of the 
term "hormone" by the protagonists was recurrent, and not justified: it was not an inappropriate use of a word, but it was a central part of the model that guided the experiments. The exclusive attention paid to the non-autonomous characters, vermilion and cinnabar, also becomes obvious: if genes act through the production of hormones, from the very definition of hormone action the characters had to be non-autonomous. The abandonment of this "hormonal" model was slow and progressive, which also explains why the relation one geneone enzyme was not immediately placed at the pinnacle by Beadle. The experiments on Neurospora were initiated as a return to an empirical strategy to determine experimentally the products of gene action, a reorientation of the work triggered by the disappointment of not having found the hormones involved in development.

Other indirect observations are also in favour of the existence and influence of this model. I will briefly describe two of them. The first is the representation of gene structure proposed by the Russian biologist Koltzoff (Koltzoff 1939; Morange 2011). Often mentioned as the first model of gene structure, it is also criticized for its naivety, and the heterogeneity of the chemical molecules supposed to form the genetic material. To a long polypeptide chain, Koltzoff attached amino acids and hormones. The presence of hormones in the genetic material was retrospectively considered as absurd, whereas it had its full significance in a hormonal model of gene action.

Frauds and/or non-reproducible experiments can also be used to gain access to the range of expectations dominant at a given time. The results of experiments will be accepted too rapidly (or invented in the worst case) if they support the non-explicit model that researchers have in mind. The experiments performed by Franz Moewus in Richard Kuhn's lab on the hormonal control of sex-types in the alga Chlamydomonas 
between 1938 and 1940 belong to this category of experiments that were received with suspicion, and never confirmed (Philip and Haldane 1939; Sapp 1990). In his work, Moewus claimed to have demonstrated that the differentiation of the sex types was due to a cascade of hormones of the $\beta$-carotenoid type. The synthesis of these hormones was the result of enzyme activities controlled by genes. Interestingly, the model proposed by Moewus at a time (1938-1940) when the hormonal model was facing increasing difficulties mixed the role of hormones and the gradually increasing place of enzymes in gene action.

\section{Some conclusions about this historical episode}

The hormonal model of gene action was the result of a process of coalescence of results and concepts from three rapidly growing disciplines: biochemistry (endocrinology), genetics, and embryology. It has been already mentioned by historians that the period 1930-1940 was a time of unification in biology (Smocovitis 1992). The emergence of the modern evolutionary synthesis was the most obvious sign of this unification. The hormonal model of gene action might have been another example of unification, supported by the rapid progress made in the characterization of hormones and of the mechanisms of embryogenesis, and by the increasingly central role of genes in biological explanations. But the model remained in an embryonic form, and never reached the adult stage, where it would have been described in articles and books, and discussed at scientific meetings.

Scientific developments also follow rapid rhythms and are subject to fashions. 1933-1935, the years crucial for the experiments on Drosophila and Ephestia, as well as for the chemical characterization of the organizer (Waddington et al. 
1933; Witkowski 1985), were those when the Nobel Prize in Physiology or Medicine was awarded to Morgan (1933) and to Spemann (1935). No doubt that, during these years, genes and embryonic induction were present in the minds of many biologists!

A last lesson from this historical episode is that science functions well. The hormonal model did not find experimental support, whereas a close relation between genes and enzymes was progressively strengthened. The first model was rapidly abandoned without resistance, and the transition occurred smoothly, so smoothly that it became invisible to those who retrospectively studied these experiments. The fact that the hormonal model was never made fully explicit probably facilitated its disappearance.

\section{Acknowledgements}

I am indebted to David Marsh for critical reading of the manuscript.

\section{References}

Armon R 2012 Between biochemists and embryologists - the biochemical study of embryonic induction in the 1930s. $J$. Hist. Biol. 45 65-108

Beadle G 1945 Biochemical genetics. Chem. Rev. 37 15-96 Beadle GW 1974 Recollections. Annu. Rev. Biochem. 43 1-14 Beadle GW and Ephrussi B 1935 Transplantation in Drosophila. Proc. Natl. Acad. Sci. USA 21 642-646 Beadle GW and Ephrussi B 1937 Development of eye colors in Drosophila: diffusible substances and their interrelations. Genetics 22 76-86 
Beadle GW and Tatum EL 1941 Genetic control of biochemical reactions in Neurospora. Proc. Natl. Acad. Sci. USA 27 499-506

Berg P and Singer M 2003 George Beadle: an uncommon farmer (Cold Spring Harbor: Cold Spring Harbor Laboratory Press)

Burian RM, Gayon J and Zallen DT 1991 Boris Ephrussi and the synthesis of genetics and embryology in Gilbert SF ed. Developmental biology: a comprehensive synthesis, vol. $7 \mathrm{~A}$ conceptual history of modern embryology (New York: Plenum Press), 207-227

Butenandt A, Weidel W and Becker E 1940 Kynurenin als Augenpigmentbildung auslosendes Agens bei Insekten.

Naturwissenschaften 28 363-364

Ephrussi B and Herold JL 1944 Studies of eye pigments of Drosophila. I. Methods of extraction and quantitative estimation of the pigment components. Genetics 29 148-175 Gayon J 1994 Génétique de la pigmentation de l'oeil de la drosophile: la contribution spécifique de Boris Ephrussi in Debru C, Gayon J and Picard J-F eds. Les sciences biologiques et médicales en France 1920-1950 (Paris: CNRS Editions), 187-206

Horowitz NH 1990 George Wells Beadle (1903-1989).

Genetics 124 1-6

Kay LE 1993 The molecular vision of life (Oxford: Oxford University Press)

Koltzoff NK 1939 Les molécules héréditaires (Paris:

Hermann)

Morange M 2011 The attempt of Nikolai Koltzoff (Koltsov) to link genetics, embryology and physical chemistry. J. Biosci.

36 211-214

Needham J 1931 Chemical embryology (Cambridge:

Cambridge University Press) 
Olby R 1974 The path to the double helix (London: MacMillan)

Philip U and Haldane JBS 1939 Relative sexuality in unicellular algae. Nature 143334

Rheinberger H-J 2000 Ephestia: the experimental design of Alfred Kühn's physiological developmental genetics. J. Hist. Biol. 33 535-576

Sapp J 1990 Where the truth lies: Franz Moewus and the origins of molecular biology (Cambridge: Cambridge University Press)

Smocovitis VB 1992 Unifying biology; the evolutionary synthesis and evolutionary biology. J. Hist. Biol. 25 1-65 Sturtevant AH 1920 The vermilion gene and gynandromorphism. Proc. Soc. Exp. Biol. Med. 51 325-327 Sturtevant AH 1932 The use of mosaics in the study of the developmental effects of genes. Proc. Sixth Int. Cong. Genetics 1 304-307

Tatum EL and Beadle GW 1940 Crystalline Drosophila eyecolor hormone. Science 91458

Thimann KV and Beadle GW 1937 Development of eye colors in Drosophila: extraction of the diffusible substances concerned. Proc. Natl. Acad. Sci. USA 23 143-146 Van Overbeek J 1935 The growth hormone and the dwarf type of growth in corn. Proc. Natl. Acad. Sci. USA 21 292-299 Waddington CH 1936 The problems of embryology. Br. Med. J. 2 862-864

Waddington CH, Needham J and Needham DM 1933

Physico-chemical experiments on the amphibian organiser.

Nature 132239

Witkowski J 1985 The hunting of the organizer: an episode in biochemical embryology. TIBS 10 379-381 